\title{
Local government and good governance: The case of Samoa
}

\author{
Commonwealth Journal of Local Governance \\ Issue 7: November 2010 \\ http:/lepress.lib.uts.edu.au/ojs/index.php/cjlg
}

\section{Desmond Uelese Amosa}

School of Management and Public Administration

University of the South Pacific

\begin{abstract}
Samoa is one of the many small developing countries that are now joining the international call to strengthen local government in a global effort to advance this institution as a recognized force for positive development, especially with respect to the achievement of Millennium Development Goals (MDGs). Part of the process includes the introduction of good governance practices through capacity building in order for local government to become proficient in managing resources and to be efficient and effective in service delivery. Accountability and transparency are central to the capacity building process. This paper finds that these central principles of good governance are neither novel nor foreign to the cultural and social practices of local government in Samoa. Hence, it is argued that any attempt to build the capacity of local government in Samoa should involve enhancing and embracing those established cultural measures that underpin accountability and transparency.
\end{abstract}

\section{Introduction}

Good governance in the form of greater accountability and transparency at the local government level has been in the spotlight in recent years. Local government has been identified as a potential institution to assist central government in driving development, especially in small developing countries. The call for sound governance practices at the local level is therefore warranted for a number of reasons. In particular, decentralization of authority and the transfer of public resources from the central government to local authorities require proper reporting relationships and transparent decision-making. 
As in the case of other small developing countries, local government in Samoa is currently receiving considerable attention from the central government and donors as a potential institution and partner for development. Several initiatives have been undertaken in recent years to slowly build and strengthen the capacity of local government in the country, including a capacity building program funded through the Commonwealth Local Government Forum (CLGF), and a United Nations Development Program (UNDP) that is currently underway. Central to this program is the effort to introduce good governance principles of accountability and transparency to ensure proper decision-making at the local level when resources are provided by central government.

The intention of this paper is to make a case that accountability and transparency mechanisms are already entrenched in the cultural and social structure of local government in Samoa. This understanding is important for several reasons. First, donors, foreign consultants and central government officials responsible for capacity building efforts often fail to recognize the cultural practices and traditional mechanisms in place that are useful for their purpose. Second, in the absence of this knowledge, new measures and practices that run counter to these traditional settings may be introduced and the results are sometimes counterproductive. Third, donors and foreign consultants often use an inappropriate 'one size fits all' approach when it comes to fixing governance problems in small developing countries. Finally, it must be realized that when speaking of local government in Samoa, one is in fact talking about the traditional council of chiefs and system of governance as it applies to each village. The council of chiefs exercises all forms of power in the village, a stark contrast to the parliamentary system where there is a strong separation of powers. Promoting new forms of governance at the local level is therefore a very sensitive issue, particularly when proposed ideas or changes to local governance are seen to impact upon the council's authority in controlling village affairs.

It should be made clear from the outset that this paper does not attempt to evaluate the current CLGF-UNDP capacity building project, nor does it suggest that this project fails to recognize the traditional governance structure of local government in Samoa. On the contrary, this paper seeks to highlight the fact that there are traditional mechanisms in place that underpin the practice of accountability and transparency in local government, and 
therefore that any process of capacity building requires a thorough examination and strengthening of those mechanisms. The CLGF-UNDP project is attempting precisely that approach.

In presenting the analysis, the focus is mainly on the council of chiefs and how its fono (meeting) protocols enforce accountability for council members and transparency in decision-making. This is not to say that the fono is the only mechanism for accountability and transparency in local government in Samoa. There are in fact other mechanisms but they are beyond the scope of this paper. Also, whilst references are made to the parliamentary model that applies to central government practices in Samoa, no attempt is made to present a comparison between the two models. Such a task requires further extensive research.

\section{Accountability and Transparency in Local Government}

Accountability and transparency remain the fundamental principles that ensure the proper functioning of government administration, be it at the central or local level. Both principles are central to good governance and continue to be pivotal in ensuring that those in power are discharging their functions and duties honestly and legitimately. Both terms are not short of definitions. Accountability can be seen to be about an "authoritative relationship in which one person is formally entitled to demand that another answers for (that is, provide an account of) his or her actions; rewards or punishments may be meted out to the latter depending on whether those actions conform to the former's wishes” (Harmon 1995:25). Transparency on the other hand is about 'self-disclosure' or the 'opposite of secrecy' (Florini 2002).

In the central government context, both concepts become complex and ambiguous. Political accountability is often addressed at this level. In general, it is a way of upholding sound democracy, where ministers are asked directly by parliament and the public to explain their actions and rationales for their decisions (Lamour 1998). In fact, the survival of organizations and the legitimacy of programs are the prerogatives of political accountability (Jabbra and Dwivedi 1989). Managerial accountability also attracts attention at the central government level as it deals mainly with public officials. This form of accountability is about 
making those public officials with delegated authority answerable for carrying out agreed tasks according to accepted criteria of performance (Day and Klein 1987:27).

Transparency in central government is about information openness and accessibility, including presenting clear, unambiguous information on government rules and procedures (Zurawicki 2003). The OECD (2001) divides transparency into two streams; regulatory transparency and information transparency. The former is about making the legislative process widely open to the public, coupled with clear directions on how one can appeal decisions. The latter ensures the availability of statistical and other information on government operations in a timely manner for interested parties and the general public's consumption (OECD 2001). Transparency can also be described as making public policy accessible and understandable in order to control abuse and to reduce cost and uncertainty (Helble et. al. 2007; Mitchell 1998).

Local government is no exception when it comes to accountability and transparency. Shah (2006) stresses the need to develop a governance framework that incorporates responsive, responsible and accountable local government that engages in local service delivery. The United Nations through its Human Settlements Program (2004) also recognizes the urgency to promote accountability and transparency in local government if decentralization of service delivery is to be effective. In doing so, four strategies are recommended:

1. monitoring of transparency;

2. access to information and public participation;

3. promotion of ethics, professionalism and integrity

4. institutional reform (United Nations Settlements Program 2004).

The same message also features in the Commonwealth's vision for improving local government. Accordingly, citizens and voters need to be empowered in order to put pressure on elected representatives to improve service delivery (Amis 2009). The Aberdeen Agenda, which was endorsed by Heads of Commonwealth countries in 2005, outlines 12 principles of good governance that should underpin democracy at the local level in member countries (Amis 2009:2). Accountability and transparency are amongst the adopted principles. 
As members of the Commonwealth and the United Nations, Samoa and other Pacific Island Countries (PICs) in recent years and presently have responded positively to the wider call for building a sound governance framework as the platform for local democracy. The Commonwealth, through the CLGF Pacific Project, is spearheading this campaign in the region through a series of capacity building projects. ${ }^{1}$ This follows the recommendations of a regional symposium held in Fiji in 2004 (Commonwealth Secretariat 2005).

\section{Local Government in the Samoan Context}

The fundamentals of local government are not new to Samoan society. Traditionally, the social structure of Samoa clearly outlines the status, roles, responsibilities, values, rules and jurisdictional boundaries of Samoans at the village and district levels. During the colonial era $^{2}$ there was attention directed to developing a 'modern' local government structure alongside that of the central government (Afamasaga 2006). In 1950, a Commission was set up to examine ways to integrate both systems effectively (Afamasaga 2006). However, at the time of independence in 1962 the existing traditional system of village governance was retained.

Since independence, several initiatives have been taken to further develop local government as a potential partner for development. These include the establishment of the Ministry of Internal Affairs in 1990 and the passing of the Fono Act 1991, and the Internal Affairs Act 1995. The Ministry was later reduced to a Division of Internal Affairs and Rural Development (DIRD) within the Ministry of Women's Affairs and Social Development following the restructuring of government departments in 2005. At present DIRD is working closely with partner agencies including CLGF and UNDP in strengthening capacity for decision-making in local government.

\section{Social structure of local government}

The social structure of local government in Samoa is comprehensive (Figure 1) and applies in a broadly similar manner to all traditional villages. ${ }^{3}$ In essence, it clearly highlights the respective authority and roles of various institutions and individuals in Samoa's society.

\footnotetext{
1 These are funded largely by the New Zealand and Australian aid programs.

2 For more details on the political history of Samoa see Meleisea and Meleisea 1987; Meleisea, 1987.

3 There are a substantial number of non-traditional villages, both in rural areas settled by non-indigenous people and also in recently developed urban areas.
} 
Located at the apex of the pyramid are those individuals (men and women) who hold matai (chiefly) titles. ${ }^{4}$ This group is the supreme authority in the traditional Samoan village and is normally referred to as the pulega a matai or the council of chiefs. Every aiga (family) in the village is represented in the council through its matai. Some may have more matai than others, depending on the size of the family. There is no rule on the number of matai for each family. This is at the discretion of the Sa'o, or the paramount chief of the family and his/her family members.

The fa'avae or the constitution is central to the operation of the village council. An integral component of the village fa'avae which is called the fa'alupega establishes the status and roles of each matai in the village council. The village constitution is unwritten: it consists mainly of the beliefs and values of that particular village and its rules approved over time as well as precedents. The aualuma (women's committee) traditionally comprised girls and women who belong to the constituent families of the village by birth. This included women matai and female relatives of male matai, but not their wives. This practice was an attempt to avoid conflict of interest as the aualuma is advisory to the council which is the ultimate decision making body. The taulele'a or aumaga (young men without a chiefly title) serve the village council and to some extent the aualuma if there is a need.

In most villages the auluma has been supplemented or replaced by a broader women's komiti. This includes all women in the village: members of the auluma, wives of matai and women born outside the village who have married untitled men (Schoeffel 1977).

\section{Roles, responsibilities and values}

The council as discussed earlier is the supreme authority in the village. Its main role is to make rules for the welfare and security of villagers. The same authority also enforces the rules and adjudicates on village members who are accused of violating those rules. It also acts as a mediator to resolve family disputes in the village, especially amongst families who are going through a dispute over land or titles that is before the Lands and Titles Court. ${ }^{5}$ This

\footnotetext{
${ }^{4}$ It should be noted that not all villages in Samoa allow women to hold matai titles and in some cases female matai are excluded from the fono.

${ }^{5}$ For more information on the role of Lands and Titles Court, see: Tuimaleali'ifano (2005).
} 
role of the village council remains intact at present and it is viewed as one of the pillars for stability at the village and national levels.

The aualuma or komiti occupy several roles. Traditionally, the auluma was concerned with maintaining peace and harmony in the village. This function underscored the role of women in their families. Another important role of the two bodies is to produce wealth for the village and individual families. This is normally in the form of ietoga (fine mats) and other Samoan artifacts. In addition, they are responsible for health and education matters, for instance, women are mainly tasked with hygiene and sanitation issues in the village. They also provide support for various government health campaigns and related projects. More recently, the komiti has become a point of liaison with central government through the appointed women's representative (sui-ole-malo).

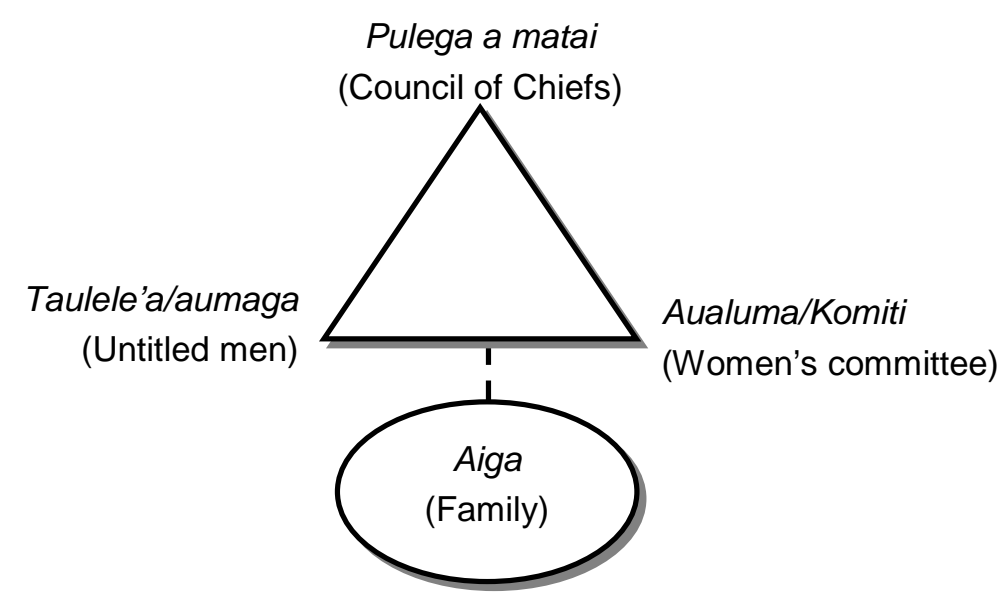

Figure 1: Social structure of local government in Samoa

In the Samoan culture, the taulele'a or aumaga is called malosi o le nu'u, which literally means 'the strength of the village'. This label mandates the main roles of the aumaga. Paramount to the aumaga's role is its obligation to serve the village council faithfully by implementing and enforcing its decisions. The aumaga is also obligated to provide assistance to the families of the village when in need, mainly in the form of labor. The provision of 
food is also one of the priorities of the aumaga and is the main reason why young Samoan men are engaged in farming and fishing activities on a daily basis. ${ }^{6}$

The roles and responsibilities of these three arms of local government thus reflect the cultural values of Samoans. To date, comprehensive studies on those values are limited. That said, Hofstede's (1999; 2001) renowned cultural values framework is used here to illustrate some Samoan cultural beliefs. It is beyond the scope of this paper to give a full account of Hofstede's work, however, it is widely accepted that there are five dimensions that explain cross-cultural differences amongst countries. These are:

1. power distance

2. individualism versus collectivism

3. uncertainty avoidance

4. masculinity versus femininity

5. long-term versus short-term orientation (Hofstede, 1999; 2001).

For the purpose of this discussion, the dimensions of 'power distance', and individualism versus collectivism are useful concepts. The idea of 'power distance' refers to the acceptance (or otherwise) of unequal power distribution in a society (Hofstede 2001). Societies at the higher end of the scale accept the existence of uneven power distribution, whilst those at the opposite end of the spectrum do not believe that there is uneven power distribution within their own society. Individualism refers to societies where individuals value independence over being a member of a community. On the contrary, societies that value collectivism culturally prefer to work together as a community in harmony. Samoa is on the higher side of power distance. Samoans traditionally believed that their chiefs are chosen by God and therefore they have the right to rule and to make decisions. This belief is instrumental to the Samoans respect for their chiefs and therefore of the council of chiefs as the ultimate authority in the village setting. The elders or senior members of society and church ministers are similarly respected: elders for their contribution to society and their institutional knowledge, and ministers as representatives of God.

\footnotetext{
${ }^{6}$ For more discussion on the structure and the respective roles of the matai, aualuma and auamaga, please see: Iati 2000; Schoeffel 1977; Schoeffel and Turner 2003.
} 
Collectivism is also a trademark of Samoan cultural beliefs. Its origin is in the family and its practice spreads to the village level and beyond. A family in the Samoan context is largely understood in the form of the extended family rather than the immediate family. In this setting, other values that are strongly linked to collectivism like sharing, hospitality, respect, love, support and loyalty amongst others are practiced in one form or another. For instance, it is a norm in the Samoan culture for one family to borrow cooking ingredients from another without compensation.

\section{Decision-making in the Council of Chiefs}

Decision making in the council of chiefs can be seen to follow democratic principles comparable to those underpinning the parliamentary model. When the council sits in its monthly fono, or meeting (as is the practice in most villages), the tu'ua (the most senior orator) who is the chair of the meeting opens the proceedings. It is also the tu'ua's role as the chair to oversee the progress of the fono and to ensure proper procedures and protocols are followed. The failautusi (secretary) presents the agenda which is comprised of outstanding matters and new items brought forward by council members or any family or individual in the village.

Once the agenda is read out, the council decides which matters are of priority. Usually, the matters that threaten stability and peace in the village are dealt with urgently. This always applies in the case of a family or a member of the village that has committed a serious offence like murder, rape or other acts of violence. These are sensitive and emotional matters, as chiefs from the victim's family and the perpetrator are all present in the meeting. The important matters are discussed last in the meeting.

The process that takes place before reaching a final decision is central to the practice of democracy, accountability and transparency in the council's proceedings. The first round of speakers on any subject is mainly based on the village fa'avae and the fa'alupega. The latter provides guidance for chiefs who are expected to speak in the first round of discussion. The order of speaking is based on the status and role of every chief in the council. When the council meets, each chief is aware of his/her appropriate moment to speak. Usually, those chiefs with paramount status are included in the first round. Once the first round is 
completed, it is a common practice to open the floor to anyone in the council who wishes to contribute to the discussion. This normally constitutes the second round of discussion. The third round is basically the summing up of viewpoints and this is conducted by those who took part in the first round. The tu'ua in his/her capacity as the chair of the meeting is the last person to speak and to make the decision. Normally the decision is based on the direction favoured by the majority opinion. Before the decision is final the $t u$ 'ua has to check with others who hold a contrary view for the last time to ensure consensus in council. If there is no objection, the decision becomes final.

In the event that there is an objection, the discussion is opened up again and the process of first and second round discussion is recalled. This practice often applies to complex, emotional and new problems. Sometimes, a final decision is reached after several rounds of discussions. In other cases a consensus may not be within sight after a long day, and the decision is deferred to the next fono. This practice is referred to in Samoan as moe le toa. ${ }^{7}$ This phrase originated from past times of war: it literally means to rest and to find strength for the next day. Samoans believe that this is the moment when the warriors pray to the spirit of their ancestors to bring strength and courage for the next day. The same meaning applies when the concept is used in the council meeting. It simply means that the decision is deferred to the next meeting in order for every chief to pray to the spirit of their ancestors to help guide them to a good decision for the benefit of everyone. Depending on the urgency of the matter, the next meeting could be the very next day or the next monthly meeting.

There are more than 300 villages in Samoa. The practice outlined above may vary from one village to another. However, the fundamentals of consensus and the opportunity to voice one's opinion in the fono remain the essence of decision making in the village council.

\section{The Fono as an Accountability and Transparency Mechanism}

The previous discussion suggests that the fono stands as one of the primary mechanisms for accountability and transparency in local government in Samoa. Council members, families and individuals in the village are held accountable for their actions (or lack of actions)

\footnotetext{
7 Toa is the name of the wood that was used as a weapon for war.
} 
through the process discussed earlier. For instance, a council member who fails to follow a council's decision is mandated to appear in the fono. He or she is given the opportunity to explain and to defend his/her action before the council deliberates on a decision. The deliberation follows the procedure explained in the previous section. In the end, the member concerned is penalized if he/she is found guilty, and the weight of the punishment depends on the severity of the offence.

The question of who holds the council or the decision-makers accountable for a poor decision becomes the centre of attention here. Traditionally, Samoans believe that the council is accountable to God for the decisions that it makes. ${ }^{8}$ This may sound outrageous, but there are strong cultural practices and beliefs that support such conviction. One for instance refers to the ritual of bestowing matai titles. This ritual starts with the 'ava (kava) ceremony and according to the Samoan custom, this is about worshipping the gods of the Samoans. ${ }^{9}$ In the context of bestowing titles, the 'ava ceremony gives the village council the opportunity to thank God for its guidance to the family's paramount chief (Sa'o) for choosing those members of his/her family who are receiving the matai titles. Part of the council's representative speech also asks God to bless the family members chosen to become matai. Importantly, the bestowing of matai titles cannot be completed without the 'ava ceremony and the participation of the village council.

What this means is that, when the council makes a poor decision, God punishes those who were at the centre of such decision. This mainly comes in the form of severe illness (even death) or a curse to the members of the families of those who promoted such a decision in council. This curse is mainly referred to in Samoa as mala aunu'ua, which literally means a village curse. The Samoans believe that God would hear the villagers' pain and suffering and therefore punishes those in the council responsible for such decision. While this may sound odd, the matai in Samoa are fully aware of such belief and are very cautious when making decisions in council.

\footnotetext{
${ }^{8}$ Based on the interviews with Tui Atua Tupua Tamasese Efi and Maulolo Tavita Amosa

9 Samoans worshipped many gods before the arrival of Christianity. Samoa is now a Christian country and believes in one God worshipped by the Christian faith.
} 
The strength of the fono as a mechanism to guarantee accountability in the village and in the council lies in several respects. The members of the council are not elected, they are appointed by the members of their respective families as chiefs for life. They are therefore members of the council throughout their entire lives, unless they are banned from the council or dishonoured by their families. Council members do not have to go through a political campaign in which they may be forced to make unrealistic promises to the voters as in the case of a parliamentary system. Nor are they obligated to look for financial support from individuals and organizations to fund their election campaign. Hence, when making villagers, families or council members accountable for violating a council's decision there is no pressure to manipulate the process to exonerate the offender because he/she is a voter or a financial sponsor for an election campaign.

Another quality of the fono is the absence of political parties. Unlike the parliamentary model where partisanship features prominently, the fono can be seen as a 'one-party' institution. This makes the accountability process effective and robust. There are no hidden political agendas amongst some members of the council to bail out an offender because of affiliation to their political parties. Council members irrespective of their status in the council and the village are therefore subjected to the same process and treatment. While there are rivalries, bickering, bargaining and coalition amongst chiefs internally at times, the system is transparent enough to keep the council in line with the values and principles underpinning its constitution.

Unlike the parliamentary model where there is a clear separation of the legislative, executive and judiciary powers of the state, the council of chiefs holds all three powers. Firstly, this gives more merit and strength to upholding accountability and transparency in the council fono. In particular, the deliberations are held in front of every council member. Unlike a system where Cabinet and political parties meet in secrecy or separately, the fono is an open forum where chiefs freely debate and boldly express their opinions in the presence of everyone. In this context, it is highly unlikely that accountability will be undermined. Secondly, the judicial process is simple and short. Anyone in the council or the village committing an offence is expected to face the council in the next fono. In serious cases that 
involve murder, rape, and violence, the process is much swifter in order to keep stability and peace in the village.

\section{Lessons for Capacity Building Programs}

What has been highlighted earlier in this paper should assist policy makers, donors and consultants engaged in the task of capacity building for local government in Samoa and other Pacific Island Countries (PICs). A useful starting point is to identify what local government means to the country concerned. Often in PICs, it refers at least in part to traditional authority and administration at the village level as in the case of Samoa, or at the provincial level in the case of Fiji (for more details see Hassall and Tipu 2008). A sound appreciation of these variations provides useful guidance in understanding roles and jurisdictional boundaries that may impact on or be affected by capacity building exercises. Any action intended or otherwise - that would alter these traditional boundaries of jurisdiction through capacity building could be met with strong resistance as it could be viewed as a lack of respect for traditional authority.

Sound knowledge and respect of cultural practices in local government is also an essential requirement. Pacific Island Countries including Samoa are not short of local experts who are well versed in their own culture and can provide important advice to those spearheading capacity building campaigns. As is evident in the case of Samoa, most of the elements central to capacity building for good governance are already entrenched in the traditions of local government in that country, and similar practices can be found in other PICs. Having genuine insight into these cultural practices and beliefs enables development partners to build on those traditions. This strategy is important as it gives an assurance to local authorities and people that their traditional practices are important and deserve recognition and strengthening. In return, locals are more likely to be supportive of capacity building initiatives. By contrast, failing to recognize traditional practices and beliefs could have disastrous consequences for capacity building.

There are several ways in which traditional practices could be enhanced. For instance, members of a particular community could be reminded of the importance of maintaining and strengthening their practices through community awareness workshops. In addition, new 
initiatives could be introduced as supporting measures. In Samoa, for example, the fono could be encouraged to document and to preserve all its decisions for the council's reference in the future. This type of approach is being applied by the current CLGF-UNDP project.

It is also important to understand that cultural practices in local governance vary significantly from one country to another. While there are similarities across PICs, there are also some fundamental differences. Often, consultants and donors paint different countries with the same brush, especially when it comes to small developing countries, and this can result in a failure to recognise important details that are relevant to the effort to strengthen local government.

\section{Conclusion}

Samoa's case as discussed in this paper shows that accountability and transparency are not foreign ideas to local government in that country. The fono is ingrained with traditional protocols that ensure democratic deliberations and hold village council members accountable in a transparent way. Capacity building for local government in Samoa should therefore focus on strengthening fono proceedings and protocols to ensure its effectiveness in upholding accountability and transparency. There are, however, some fundamental differences in cultural practices of local governments in Pacific Island Countries. While local government in Samoa exhibits a high level of accountability and transparency mechanisms, practices in some other countries may not have the same advantages, and different approaches to capacity building may be warranted.

\section{References}

Afamasaga, T. (2006) 'Strengthening Local (Village) Government', Unpublished.

Amis, P. (2009) Improving Local Government: The Commonwealth Vision, Background Discussion paper for the Commonwealth Local Government Conference, Freeport, Grand Bahama, 11-14 May 2009.

Commonwealth Secretariat (2005) Local Democracy and Good Governance in the Pacific, Report of the Regional Symposium held in Suva, Fiji Islands, December 2004.

Day, P. and Klein, R. (1987) Accountabilities: Five Public Services, Tavistock Publications, London and New York.

Florini, A (2002) 'Increasing Transparency in Government', International Journal on World Peace, 2(3): 3-37.

Harmon, M. (1995) Responsibility as Paradox: A critique of Rational Discourse on Government, Sage, California and London. 
Helble, M., Shepherd, P and Wilson, J. (2007) Transparency and Trade Facilitation in the AsiaPacific: Estimating the Gains from the Reform, World Bank Development Research Group, Washington, DC.

Hassall, G. and Tipu, F (2008) 'Local Government in the South Pacific Islands', Commonwealth Journal of Local Governance, 1, May 2008.

Hofstede, G. (1999) 'Problems Remain, But Theories will Change: The Universal and the Specific in the $21^{\text {st }}$ Century Global Management', Organizational Dynamics, 28(1): 34-44.

Hofstede, G. (2001). Culture's Consequences: Comparing Values, Behaviors, Institutions, and Organizations across Nations ( $2^{\text {nd }}$ ed.), Sage Publications, California.

Iati, I. (2000) 'The good governance agenda for civil society: Implications for the Fa'asamoa, in E. Huffer and A. So’o Eds) Governance in Samoa: Pulega i Samoa, Asia-Pacific Press, Australia National University, Canberra.

Jabbra, G. J. and Dwivedi, P. O. (eds) (1989) Public Service Accountability: A Comparative Perspective, Kumarian Press, Connecticut.

Lamour, P. (1998) 'State Society and Governance in Melanesia', Paper presented to the South Pacific Ombudsmen Workshop held at the Australian National University.

Meleisea, M. (1987) The Making of Modern Samoa: Traditional authority and Colonial Administration in the history of Western Samoa, Institute of Pacific Studies, University of the South Pacific, Suva, Fiji.

Meleisea, M and Meleisea, P. (1987) Lagaga: A short history of Western Samoa, Institute of Pacific Studies, University of the South Pacific, Suva, Fiji.

Mitchell, R. (1998) 'Sources of Transparency: Information Systems in International Regimes', International Studies Quarterly, 42(1): 109-130.

OECD, (2001) Flagship report on Regulatory Quality, Organization for Economic Cooperation and Development, Paris.

Shah, A. (2006) 'A Comparative Institutional Framework for Responsive, Responsible and Accountable Local Government, in A. Shah (ed) Local Governance in Industrial Countries, World Bank, Washington, DC.

Schoeffel, P. (1977) 'The origin and development of women's associations in Western Samoa, 18301977, Journal of Pacific Studies, 1(3): 1-21.

Schoeffel, P. and Turner, M. (2003) Local-level governance in the Pacific, in State, Society and Governance in Melanesia, Discussion Paper (2003/7), Research School of Pacific and Asian Studies, Australia National Univeristy.

Tuimaleali'ifano, M. A. (2005) Aiga ma o Latou Tama: Anatomy of Ancient Hierarchy and Roots of Political Corruption, Institute of Pacific Studies, University of the South Pacific.

United Nations Human Settlements Program, (2004) Tools to Support Transparency in Local Governance, United Nations Human Settlements Program, Nairobi, Kenya.Zurawicki, L. (2003) Nothing to Hide, Everything to Gain: Transparency and FDI, Organization for Economic Cooperation and Development, Paris. 